\title{
СТІЙКІСТЬ ВИХІДНОГО МАТЕРІАЛУ СОНЯШНИКУ ДО НОВИХ РАС BOBYKA (OROBANCHE CUMANA WALLR.)
}

К. М. Макляк , В. В. Кириченко

Інститут рослинництва ім. В. Я. Юр'єва НААН

У статті наведено результати досліджень 2010-2011 років з вивчення вихідного матеріалу для селекції гібридів соняшнику, створеного в Інституті рослинництва ім. В. Я. Юр'єва НААН, за стійкістю до рослини-паразита вовчка (Orobanche cumana Wallr.). Вивчено расовий склад популяції вовчка, насіння якого зібрано на посіві місцевого сорту в Амвросіївському районі Донецької області. Виділено лінії-закріплювачі стерильності, стійкі до нових рас вовчка.

Соняшник, селекиія, вовчок, расовий склад, стійкість

Вовчок соняшниковий (Orobanche cumana Wallr.) - це квіткова рослина - облігатний паразит, широко розповсюджений в Україні. Він спричиняє значні збитки врожаю в Одеській, Миколаївській, Херсонській, Запорізькій, Дніпропетровській, Донецькій, Луганській областях, а також в окремих районах Харківської, Кіровоградської і Черкаської областей [1]. При сильному ураженні (60 квітконосів паразита на рослину соняшнику) вовчок може практично повністю знищити врожай [2].

Вовчок, як і соняшник - перехреснозапильна рослина, завдяки чому зберігає постійну неоднорідність за патогенністю. Популяція вовчка складається з спеціалізованих форм (фізіологічних рас), які різняться між собою за здатністю уражувати або не уражувати окремі генотипи (сорти, гібриди, лінії) [3]. Природний добір на фоні відібраних людиною стійких зразків рослини-живителя, подібно селекційному добору, виділяє такі біотипи вовчка, які здатні до подолання стійкості соняшнику і виживання. Більш вірулентні біотипи швидко розмножуються та уражують раніше стійкі генотипи соняшнику [4], утворюючі нові фізіологічні раси. Це вимагає постійного проведення селекційної роботи, спрямованої на створення вихідного матеріалу, стійкого до комплексу нових рас вовчка.

Дослідження вчених Інституту рослинництва ім. В. Я. Юр'єва НААН, спрямовані на пошук та вивчення біотипів соняшнику, стійких до вовчка, розпочато у 60-ті роки XX століття. Повна відсутність на той час стійкості сортів соняшнику до нових рас вовчка змусила проводити пошук джерел стійкості серед дикорослих видів роду Helianthus. Шляхом схрещування соняшнику 3

(C) К. М. Макляк, В. В. Кириченко. 2012. ISSN 0582-5075. Селекція і насінництво. 2012. Випуск 102. 
однорічними та багаторічними дикорослими видами було виділено джерела стійкості до основних збудників хвороб соняшнику та до вовчка [4]. На основі багаторічного гексаплоїдного виду Helianthus tuberosus L., використовуючи парні і насичуючі схрещування та індивідуальний добір на жорсткому інфекційному фоні, було створено різноманітні за морфологічними та господарськими ознаками форми, стійкі до вовчка [6, 7].

Розробка методик створення інфекційного фону для прояву такого рівня ураженості, який дозволить виявити зразки з генетично детермінованим рівнем стійкості, є основою селекції на стійкість до патогенів. У 80-ті роки, предметом досліджень селекціонерів інституту було вивчення впливу інфекційного навантаження, кількості рослин у сосудах, термінів зберігання насіння вовчка, періоду освітлення на ступінь ураження рослин [8]. Результатом став модифікований метод діагностики стійкості до вовчка в умовах штучного клімату [9]. Завдяки використанню в інституті штучного клімату було створено новий селекційний матеріал як материнського, так і чоловічого типів [10]. Так, для селекційної практики було рекомендовано лінії X 1002 Б, X 711 В, на основі яких створено комерційні гібриди соняшнику, що до теперішнього часу користуються великим попитом виробників.

У 80-ті роки повідомлялося про існування п'яти рас вовчка $(A, B, C, D$ i $E$ ). У 1997 році в Румунії було ідентифіковано расу $F$, а у 2006 році нові, більш вірулентні біотипи паразита, були названі расами $G$ і $H$ [11]. За літературними даними, лінії соняшнику, стійкі до раси $F$ вовчка, знайдено як серед дикорослих видів, так і серед культурних форм. Так, за повідомленням $\mathbf{J}$. Fernández-Martínez, з 55 проаналізованих зразків різного походження чотири виявилися стовідсотково стійкими до раси $F$, зокрема, BIP 115 і ВIP 117 [12]. Дослідженнями з успадковування стійкості соняшнику до раси $F$ вовчка встановлено складний характер успадковування. Так, за S. Sukno, стійкість визначається додатковими домінантними алелями до локусу $\mathrm{Or}$ або кластером тісно зчеплених неалельних генів [13]. За В. В. Бурловим, стійкість до раси $F$ визначається одним домінантним геном [14]. Важливим був висновок про стійкість зразків, стійких до раси $F$, до менш вірулентних рас [15].

Метою наших досліджень було визначення джерел стійкості до нових вірулентних рас вовчка серед зразків робочої колекції ліній-закріплювачів стерильності, створеної нами впродовж 1996-2005 років [16].

Насіння вовчка було зібрано на сході Донецької області в Амвросіївському районі на посіві місцевого сорту. За дослідженнями, популяція вовчка з Донецької області характеризується високою агресивністю і вірулентністю [1].

Насіння зразків-диференціаторів рас вовчка було отримано Національним центром генетичних ресурсів рослин України (м. Харків) за програмою обміну колекційним матеріалом з Академією сільськогосподарських і лісових наук (The Academy for Agricultural and Forestry Sciences (ASAS)), Бухарест, Румунія. Надані зразки включали диференціатори: раси $D$ (лінія LC 1002 В), раси $E$ (лінія LC 1003 В та гібрид $F_{l}$ ), раси $F$ (лінія LC 1093 A), раси $G$ (гібрид $F_{l}$ ), раси $\mathrm{H}$ (гібрид $F_{l}$ ) та сприйнятливу до всіх рас лінію AD-66. 
Для штучного зараження соняшнику вовчком та виявлення стійких ліній використовували умови штучного клімату (фітотрон), згідно модифікованого методу ранньої діагностики стійкості; в польових умовах інфекційний фон створювали внесенням насіння вовчка при сівбі в кожне гніздо разом із насінням соняшнику [9]. Облік ураження вовчком на штучному інфікованому фоні у польових умовах проводили наприкінці достигання. Стійкість зразків визначали за відсотком ураження (частка уражених рослин до облікових) і ступенем ураження, який визначали кількістю квітконосів у польових умовах або кількістю бульбочок паразита в умовах фітотрону на одну уражену рослину соняшнику.

Високу вірулентність донецької популяції вовчка було доведено аналізом ураженості зразків-диференціаторів рас (табл. 1). Ураженість диференціаторів оцінювали на польовому штучному фоні влітку 2010 року та в умовах фітотрону у зимовий період 2010-2011 років. Невелика кількість проаналізованих рослин кожного диференціатора (біля 20-ти) та незначна різниця у ступені ураження вовчком (від 2,0 до 8,4 бульбочок на 1 уражену рослину) не дозволили, за прикладом інших авторів, стверджувати про переважну частку тієї чи іншої раси квіткового паразита в дослідній популяції [14]. Але, за даними, отриманими як в умовах штучного клімату, так і в польових умовах, ступінь ураження вовчком гібридних комбінацій - диференціаторів рас $G$ і $H$ дорівнювала 0,0 квітконосів або бульбочок паразита, тобто у популяції були відсутні біотипи паразита із вірулентністю вищою, ніж раса $G$ (табл. 1).

Таблиця 1

Ураженість вовчком зразків соняшнику - диференціаторів рас вовчка

\begin{tabular}{|l|c|c|c|c|c|}
\hline \multirow{2}{*}{$\begin{array}{c}\text { 3разок- } \\
\text { диференціатор }\end{array}$} & \multirow{2}{*}{$\begin{array}{c}\text { Диференціатор } \\
\text { раси }\end{array}$} & \multicolumn{2}{|c|}{$\begin{array}{c}\text { Польовий штучний } \\
\text { фон, 2010 р. }\end{array}$} & $\begin{array}{c}\text { Умови фітотрону, } \\
\text { зима 2010/2011 рр. }\end{array}$ \\
\cline { 3 - 6 } & $\begin{array}{c}\text { \%ражених } \\
\text { рослин }\end{array}$ & $\begin{array}{c}\text { ступінь } \\
\text { ураження }\end{array}$ & $\begin{array}{c}\text { \% } \\
\text { уражених } \\
\text { рослин }\end{array}$ & $\begin{array}{c}\text { ступінь } \\
\text { ураження }\end{array}$ \\
\hline LC 1002 B & $D$ & 60,0 & 5,7 & 100,0 & 5,2 \\
\hline LC 1003 B & $E$ & 20,0 & 1,0 & 100,0 & 8,4 \\
\hline $\mathrm{F}_{1}$ & $E$ & 80,0 & 5,9 & 100,0 & 8,2 \\
\hline LC 1093 A & $F$ & 40,0 & 5,3 & 70,0 & 2,0 \\
\hline $\mathrm{F}_{1}$ & $G$ & 0,0 & 0,0 & 0,0 & 0,0 \\
\hline $\mathrm{F}_{1}$ & $H(?)(\mathrm{mr} 8)$ & 0,0 & 0,0 & 0,0 & 0,0 \\
\hline $\mathrm{AD}-66$ & sensitive & 100,0 & 12,0 & 100,0 & 13,6 \\
\hline
\end{tabular}

Примітка. Ступінь ураження - кількість квітконосів вовчка на одну уражену рослину соняшнику.

Ступінь ураження зразка-диференціатора раси $F$ в умовах фітотрону не перевищила 2 бульбочки на рослину, в польових умовах 5,3 квітконосів на рослину, а відсоток ураження не перевищив $70 \%$ рослин (умови фітотрону). У зразків-диференціаторів рас $D$ і $E$ ступінь ураження склала від 5,2 
до 8,4 бульбочок на рослину, а стійкі рослини не спостерігали (100 \% уражених рослин) (умови фітотрону). Також не спостерігали стійкі рослини лінії AD-66, яка не має генів стійкості до вовчка.

Вивчення колекції ліній-закріплювачів стерильності проводили в умовах фітотрону взимку 2010/2011 років та на польовому штучному фоні 2010 і 2011 років. Кількість стійких рослин дослідних ліній соняшнику варіювала від $0 \%$ до $100 \%$. Ступінь ураження кращих за стійкістю ліній варіювала від 0 до 2 квітконосів або бульбочок на рослину, а уражених рослин було не більше, ніж 7,3 \% (табл. 2). Таким чином, за ступенем ураження виділені лінії знаходились на рівні зразка-диференціатора раси $F$, а за кількістю стійких рослин перевищили його.

Таблиця 2

Ураженість вовчком ліній-закріплювачів стерильності соняшнику

\begin{tabular}{|c|c|c|c|c|c|c|c|}
\hline \multirow[b]{3}{*}{ Лінія } & \multirow[b]{3}{*}{$\begin{array}{l}\text { Родовід } \\
\text { ліній }\end{array}$} & \multicolumn{4}{|c|}{ Польовий штучний фон } & \multirow{2}{*}{\multicolumn{2}{|c|}{$\begin{array}{l}\text { Умови фіто- } \\
\text { трону зима } \\
2010 / 2011 \text { рр. }\end{array}$}} \\
\hline & & \multicolumn{2}{|c|}{2010 p. } & \multicolumn{2}{|c|}{$2011 \mathrm{p}$} & & \\
\hline & & 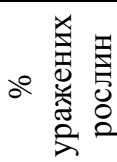 & 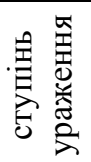 & 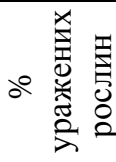 & 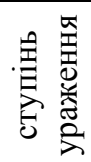 & 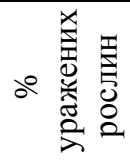 & 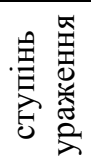 \\
\hline Х 059 Б & 1 & 0,0 & 0,0 & 3,8 & 2,0 & 0,0 & 0,0 \\
\hline X 220 Б & 2 & 0,0 & 0,0 & 0,0 & 0,0 & 0,0 & 0,0 \\
\hline X 222 Б & 2 & 0,0 & 0,0 & 2,5 & 2,0 & 7,3 & 1,3 \\
\hline X 255 Б & 3 & 6,3 & 1,1 & 0,0 & 0,0 & 0,0 & 0,0 \\
\hline $\begin{array}{l}\text { X } 908 \text { Б } \\
\text { (сприйнятлива) }\end{array}$ & & 100 & 8,9 & 100 & 9,5 & 100 & 9,3 \\
\hline
\end{tabular}

Примітка. Родовід ліній: 1 - X 908 Б / Х 4021 Б;

2 - X 2552 Б / X 1010 Б// X 503 Б / X 1008 Б/ 3 / X 503 Б/ X 1008 Б// X 1006 Б / X 3848 Б;

3 - X 503 Б / X 1008 Б // X 2552 Б / X 1010 Б.

Виділені за стійкістю лінії мають у своєму родоводі самозапилені ліній селекції Інституту рослинництва ім. В. Я. Юр'єва НААН, що різняться за стійкістю до вовчка: від низької (Х 908 Б) та середньої (X 1010 Б, Х 503 Б, Х 2552 Б, Х 3848 Б, X 4021 Б) до високої (X 1006 Б, Х 1008 Б) [17].

За тривалістю вегетаційного періоду, виділені лінії відносяться до групи ранньостиглих із періодом «сходи - цвітіння» від 54 до 56 діб (у середньому за роки вивчення).

Відомо, що тепличний і польовий методи мають певні недоліки, викликані тим, що практично неможливо створити ідеально однакові умови для кожної дослідної рослини. Тому ми з обережністю віднеслися до інтерпретації отриманих нами даних, але допустили наявність у виділених зразків генетичних детермінантів, що контролюють стійкість соняшнику до раси $F$ вовчка. 
Висновки. У ході досліджень 2010-2011 років аналізом ступеня ураження зразків-диференціаторів рас доведено високу вірулентність донецької популяції вовчка та відсутність у популяції паразита біотипів із вірулентністю вищою, ніж раса $G$. Серед зразків робочої колекції ліній-закріплювачів стерильності, створеної впродовж 1996-2005 років на основі селекційного матеріалу Інституту рослинництва ім. В. Я. Юр'єва НААН, визначено ймовірні джерела стійкості до раси $F$ вовчка (Orobanche cumana Wallr.). У подальшому, заплановано переведення виділених ліній на стерильну основу 3 метою створення експериментальних гібридних комбінацій та визначення донорських властивостей і комбінаційної здатності. Лінії включено до програми насичуючих схрещувань з лініями робочої колекції, кращих за комбінаційною здатністю.

\section{Список використаних джерел}

1. Кириченко В. В. Селекция и семеноводство подсолнечника (Helianthus annuus L.). / В. В. Кириченко. - Х., 2005. - 385 с.

2. Анащенко А. В. Местные формы подсолнечника в ЦЧО / А. В. Анащенко // - Бюл. ВИР. - Л., 1981. - Вып. 107. - С. 49-53.

3. Хатнянский В. И. Создание исходного материала подсолнечника, устойчивого к новым расам заразихи / В. И. Хатнянский // Бюл. науч.-техн. инф. по масл. культурам. - ВНИИМК, 1978. - Вып. 2 - С. 3-7.

4. Сытник М. С. Использование межвидовой гибридизации в селекции подсолнечника для условий Лесостепи УССР: автореф. дис. канд. с.-г. н.: 06.01.05 / УкрНИИРСиГ им. В.Я. Юрьева. - Х., 1972. - 23 с.

5. Сытник М. С. Получение исходных форм подсолнечника методом отдаленной гибридизации / М. С. Сытник, А. Д. Гуменюк // Селекция и семеноводство: республ. межвед. темат. наук. сб. - К., 1983. - Вып. 55. - С. 21-24.

6. Кириченко В. В. Межвидовые гибриды как исходный материал для гетерозисной селекции подсолнечника / В. В. Кириченко, М. С. Сытник // Сельскохозяйственная биология. - 1985. - № 10. - С 12-14.

7. Селекция подсолнечника на устойчивость к заразихе и усовершенствование метода ранней диагностики в условиях фитотрона / В. В. Кириченко, А. Д. Гуменюк, Е. М. Долгова [и др.] // Селекция и семеноводство : республ. межвед. темат. научн. сб. - К. : Урожай, 1987. - Вып. 63. - С. 44-46.

8. Основи селекції польових культур на стійкість до шкідливих організмів : навчальний посібник ; підгот. : В.В.Кириченко, В.П.Петренкова, I. М. Черняєва [та ін.] ; за ред. В. В. Кириченка та В. П. Петренкової / НААН, Ін-т рослинництва ім. В. Я. Юр'єва. - Х., 2012. - 320 с.

9. Аладьїна 3. К. Создание исходного материала подсолнечника, устойчивого к заразихе в Восточной Лесостепи УССР : автореф. дис. канд. с.-г. н.: 06.08.05 / УкрНИИРСиГ им. В. Я. Юрьева. - Х., 1991. - 16 с.

10. Pãcureanu-Joita M. The impact of the new races of broomrape (Orobanche cumana Wallr) parasite in sunflower crop in Romania / M. Pãcureanu-Joita, S. Raranciuc, E. Procopovici // Proc. $17^{\text {th }}$ International Sunflower Conference : Cordoba, Spain. - 2008. - Vol.1. - P. 225-230. 
11. Selection of Wild and Cultivated Sunflower for Resistance to a New Broomrape Race that Overcomes Resistance of the Or5 Gene / J. FernándezMartínez, J. Melero-Vara, J. Muňoz-Ruz [et al.] // Crop Sci. - 2000. - Vol. 40, No. 2. - P. 550-555.

12. Sukno S. Inheritance of resistance to Orobanche cernua Loefl. in six sunflower lines / S. Sukno, J. M. Melero-Vara, J. M. Fernandez-Martinez // Crop Sci. 1999 - Vol. 39. - P. 674-678.

13. Бурлов В. В. Ефективність генів Оr у забезпеченні стійкості соняшнику до нових рас вовчка (Orobanche cumana Wallr.) / В. В. Бурлов, В. В. Бурлов // Селекція і насінництво : міжвідомч. темат. наук. зб. - Х., 2010. - Вип. 98. - С. 28-37.

14. Reproductive behavior and broomrape resistance in interspecific hybrids of sunflower / S. Sukno, C. C. Jan, J. M. Melero-Vara, J. M. Fernández-Martínez // Plant Breeding. -1998. - No. 117. - P. 279-285.

15. Макляк К. М. Селекція нових ліній-закріплювачів стерильності соняшнику / К. М. Макляк, В. В. Кириченко, О. М. Брагін // Селекція і насінництво : міжвідомч. темат. наук. зб. - Х., 2009. - Вип. 97. - С. 13-19.

16. Каталог рабочей коллекции самоопыленных линий подсолнечника Института растениеводства им. В. Я. Юрьева / В. В. Кириченко, 3. К. Аладьїна, А. Д. Гуменюк [и др.]. - Х., 1996. - 84 с.

В статье приведены результаты исследований 2010-2011 годов по изучению исходного материала для селекции гибридов подсолнечника, созданного в Институте растениеводства им. В.Я. Юрьева НААН, на устойчивость к цветковому паразиту - заразихе (Orobanche cumana Wallr.). Изучены расовый состав популяции заразихи, семена которой собраны на посеве местного сорта в Амвросиевском районе Донецкой области. Выделены линии-закрепители стерильности, устойчивые к новым расам заразихи.

The article presents the results of researches of 2010-2011 years in examination of basic material for selection of sunflower hybrids created at V.Ya.Yuriev Plant Production Institute for resistance to flowering pests - broomrape (Orobanche cumana Wallr.). Race structure of broomrape popularization was studied, its seeds were gathered while seeding of local breed in Amvrosievka district Donetsk region. Sterility line-fixers resistant to new broomrape races were defined. 